\title{
Nature and Factors Affecting Tribal Labour Migration of Wayanad District of Kerala
}

\author{
V. V. Mano Sandesh*, A. Anil Kumar and K. P. Smitha
}

College of Agriculture, Kerala Agricultural University, Kerala, India

*Corresponding author

\section{A B S T R A C T}

\section{Keywords \\ Tribal migration, Nature of migration, Factors of migration \\ Article Info \\ Accepted: \\ 28 January 2021 \\ Available Online: \\ 10 February 2021}

Migration had a significant impact on the livelihood of tribes people. This had also affected the existing agriculture situation of tribal areas. The study revealed that, majority of tribal migrants were daily migrants, more than one third of the respondents were seasonal migrants and none of them migrated permanently. Tribes people migrated to other states and they moved to migratory places by induced decision. Tribal migrants went for agriculture labour work and majority were non registered migrants. The study indicated unemployment or loss of employment as the main push factor responsible for migration. Study also revealed that an over whelming majority of the respondents ranked superior opportunity for employment and occupation as first and the main pull factor responsible for migration.

\section{Introduction}

The global tribal population of approximately 300 million people is composed of about 5,000 distinct tribal cultures worldwide, living in every climate from the Arctic Circle to the tropical rain forests. The highest tribal population of Kerala, an Indian state, is found in Wayanad district. Wayanad is situated in an elevated mountainous plateau on the crust of Western Ghats at a height between 700 and 2100 meters above sea level. Wayanad has a long history of agriculture. Two tribes, who are among the inhabitants of this region from early times, and associated with earliest cultivation of rice in valley wetlands and rainfed millets in uplands, largely by shifting cultivation, are the Kurichian and the Kuruman (Prasanth, 2016). The agro ecological conditions of the area, vastly different from the plains and virtual isolation of the area from the plains due to lack of proper communication and other factors restraining early migration from the plains, the agrobiodiversity conserved and used by the native tribes eventually evolved many landraces of rice and other crops unique to the region (Das and Das, 2014). Later huge migration from plains and domination of these migrants in influencing the cropping pattern in the upland led to the total decline of millets and rise of plantation crops. An employment culture entirely based on the existing forest ecosystem limits the scope for 
adjustment to requirements of new job prospects (Vinayakam and Sekar, 2013). Yet their competency in traditional art and artisans need to be appreciated. Their spread mats, and similar household items were very popular. But now the raw materials are not easily available as access to deep forest is restricted. Forest resources like honey, bamboo products, forest medicines have been restricted to Kattunaikan tribal community. This legal restriction has led to poverty. Also labour demand especially that of women in paddy fields, has decreased, as the paddy cultivation has shrunk. The shift to cash crop cultivation like banana, ginger etc. in paddy fields has not improved their condition any better. Migration from one area to another in search of improved livelihoods is a key feature of human history (Dugbazah, 2008 and Mahapatro 2010). Migration is today a worldwide phenomenon and has become an important issue in our times (Kishore and Kiran 2013). Migration has been both a boon and a curse to humans particularly the tribal people (Sundari, 2007). Migration is necessarily a pre-empt move; it is the survival instinct that drives humans to seek better prospects (Anh, 1999). The possible causes of migration can be identified as economic reasons such as dense population and lack of means of livelihood, facility of transport, attraction of industrial centers, facility of trade and commerce. Social reasons such as access to healthcare, education, housing etc, change in social status, change in occupation status (Gowda and Shivashankar, 2007). Physical factors like facility of irrigation, availability of forest/ mineral resources, availability of new land for agriculture purposes and Political factors like wars, society tensions, ethnic/ caste clashes (Martin, 2004 and Rozelle et al., 1999). Due to many reasons like lack of employment, low job opportunities, marriage, food security, health issues, education etc many tribespeople are migrating from their native places to various parts of the country (Bagchi and Majumdar, 2010). This study attempts to evaluate the changes in the livelihood of tribespeople and agriculture system of the district due to tribal labor migration.

\section{Materials and Methods}

\section{Locale of the study}

The study was conducted in Wayanad district of Kerala state in India. This district has been purposively selected for conducting the study because this is one of the districts in Kerala having the highest concentration of tribespeople with migratory nature.

\section{Selection of sample}

The study was conducted in all the four blocks in Wayanad district namely, Mananthavady, Sulthan Bathery, Kalpetta and Panamaram From each block 30 tribal migrants, 10 tribal non migrants and 10 non tribal significant other respondents was selected randomly for the study. Thus total 120 tribal migrants, 40 tribal non migrants and 40 non tribal respondents was the sample size.

\section{Nature of migration}

It refers to the type of migration based on permanency of stay and duration of residence migration, origin and destination of movement, composition of migration and type of decision.

\section{Factors influencing tribal labour migration}

It refers to those push and pull factors responsible (reasons) for tribal labour migration.

The major push and pull factors were listed out and were given in the interview schedule. 


\section{Results and Discussion}

\section{Nature of tribal labour migration}

Study brings to light the pattern of migration of tribal migrants and the distribution of tribal migrants based on the nature of migration. Table 1 depicts that 60.83 per cent of tribal migrants were daily migrants (who migrate in the morning and return to home in the evening) and 39.16 per cent of respondents were seasonal migrants (who stay in the migrated place for a season). None of them migrated permanently.

Regarding nature of migration based on origin and destination of movement, 98.33 per cent of respondents migrate interstate and only 1.66 per cent migrated inter district. None of them migrated within local area. They migrate mostly to Coorg area via Kutta region of Thirunelli Panchayath and Karnataka via Myzore road to work as Agricultural labourers mainly for ginger cultivation.

Based on the composition of migrants all the tribal migrants move in groups. They hire a jeep and travel to migratory places. Family members may also migrate but mostly they move in different groups. Most of the tribal migrants (93.33 per cent) moved to migratory places by induced decision. Their friends and neighbors influenced their decision making on a large scale. 6.66 per cent of tribal migrants made a self decision for migration.

Regarding the purpose of migration 97.50 per cent of tribal migrants went for agriculture labour work whereas only 2.520 per cent of respondents went for non agricultural labour work. 86.66 per cent of tribal migrants were non registered migrants whereas only 13.33 per cent of tribal migrants were registered migrants. Registration was done on police stations which was found to be a non compulsory activity.

\section{Factors responsible for tribal labour migration}

\section{Push factors}

A scrutiny of Table 2 indicated that entire respondents ranked unemployment or loss of employment as first as one of the main push factor responsible for migration. Since tribal agricultural labourers had to earn their living by searching employment which pushed them to migrate. So this may be due to earn their living and to support his family.

Low wages was ranked second major push factor responsible for migration. 87.50 per cent of respondents had low wage as the major reason (push factor) for migration. The third major push factor responsible for migration was poverty and malnutrition. 71.66 per cent of the respondents migrate due to poverty and malnutrition.

Small holding was ranked fourth push factor responsible for migrate and more than half $(69.16 \%)$ of the respondents were migrated due to landlessness. 63.33 per cent of the respondents migrate due to decline of natural resources and ranked fifth major push factor.

Frustration, alienation from community and indebtedness was ranked $6^{\text {th }}, 7^{\text {th }}$ and $8^{\text {th }}$ push factors responsible for migration respectively. 52.50 per cent, 40.83 per cent and 33.33 per cent of the respondents migrate due to frustration, alienation from community and indebtedness respectively.

21.66 per cent, 20.83 per cent, 15.00 per cent and 10.00 per cent of the respondents had social conflict, oppressive of repressive discriminating treatment, retreat from community or natural calamity and plant diseases as the push factor for migration respectively. Only 1.66 per cent of respondents had lack of irrigation as push 
factor for migration it was ranked 13 among the push factors of migration.

\section{Pull factors}

A perusal of Table 3 indicated that an over whelming majority of the respondents (99.16 per cent) ranked superior opportunity for employment and occupation as first as one of the main pull factor responsible for migration.

Table also depicts that 95.83 per cent of the respondents ranked better job security as second major pull factor responsible for migration.

Superior opportunity to earn higher income, opportunity to obtain desired specialization, education, skill or training and better food ranked third, fourth and fifth major pull factors of migration respectively. 89.16 per cent, 73.33 per cent and 43.33 per cent of the respondents migrate because of superior opportunity to earn higher income, opportunity to obtain desired specialization, education, skill or training and dependency movement like migration of bride to join her husband respectively.

29.16 per cent, 17.50 per cent, 6.66 per cent and 0.83 per cent of respondents ranked Preferable environment, living conditions, Lure to new or different activities or environment, better food and better social network as sixth, seventh, eighth and ninth pull factor of migration.

Table.1 Distribution of tribal migrants based on the nature of migration

\begin{tabular}{|c|c|c|c|c|}
\hline $\begin{array}{l}\text { Sl. } \\
\text { No. }\end{array}$ & Nature of migration & Category & $\begin{array}{l}\text { No. of } \\
\text { respondents } \\
(\mathrm{N}=120)\end{array}$ & Per cent \\
\hline \multirow[t]{3}{*}{1} & \multirow{3}{*}{$\begin{array}{l}\text { Based on permanency of stay and } \\
\text { duration of residence }\end{array}$} & Daily migration & 73 & 60.83 \\
\hline & & Seasonal migration & 47 & 39.16 \\
\hline & & Permanent migration & 0 & 0.00 \\
\hline \multirow[t]{3}{*}{2} & \multirow{3}{*}{$\begin{array}{l}\text { Based on origin and destination } \\
\text { of movement }\end{array}$} & With in local area & 0 & 0.00 \\
\hline & & Inter district & 2 & 1.66 \\
\hline & & Inter state & 118 & 98.33 \\
\hline \multirow[t]{3}{*}{3} & \multirow[t]{3}{*}{ Based on composition of migrants } & One member & 0 & 0.00 \\
\hline & & With family & 0 & 0.00 \\
\hline & & In groups & 120 & 100.00 \\
\hline \multirow[t]{2}{*}{4} & \multirow{2}{*}{$\begin{array}{l}\text { Based on type of decision for } \\
\text { migration }\end{array}$} & Induced decision & 112 & 93.33 \\
\hline & & Self decision & 8 & 6.66 \\
\hline \multirow[t]{2}{*}{5} & \multirow[t]{2}{*}{ Based on purpose of migration } & Agricultural labour & 117 & 97.50 \\
\hline & & $\begin{array}{l}\text { Non agricultural } \\
\text { labour }\end{array}$ & 3 & 2.50 \\
\hline \multirow[t]{2}{*}{6} & \multirow{2}{*}{$\begin{array}{l}\text { Based on registration regarding } \\
\text { migration }\end{array}$} & Registered & 16 & 13.33 \\
\hline & & Non registered & 104 & 86.66 \\
\hline
\end{tabular}


Table.2 Push factors for migration as perceived by tribal migrants

\begin{tabular}{|c|c|c|c|c|}
\hline $\begin{array}{l}\text { Sl. } \\
\text { No. }\end{array}$ & Push factors & Total Score & Per cent & Rank \\
\hline 1 & $\begin{array}{l}\text { Unemployment or loss of } \\
\text { employment }\end{array}$ & 1560 & 100.00 & I \\
\hline 2 & Low wages & 1365 & 87.50 & II \\
\hline 3 & Poverty and malnutrition & 1118 & 71.66 & III \\
\hline 4 & $\begin{array}{l}\text { Small land holding or } \\
\text { landless }\end{array}$ & 1079 & 69.16 & IV \\
\hline 5 & Decline of natural resources & 988 & 63.33 & V \\
\hline 6 & Frustration & 819 & 52.50 & VI \\
\hline 7 & Alienation from community & 637 & 40.83 & VII \\
\hline 8 & Indebtedness & 520 & 33.33 & VIII \\
\hline 9 & Social conflict & 338 & 21.66 & IX \\
\hline 10 & $\begin{array}{l}\text { Oppressive of repressive } \\
\text { discriminating treatment }\end{array}$ & 325 & 20.83 & $\mathrm{X}$ \\
\hline 11 & $\begin{array}{l}\text { Retreat from community or } \\
\text { natural calamity }\end{array}$ & 234 & 15.00 & XI \\
\hline 12 & Plant diseases & 156 & 10.00 & XII \\
\hline 13 & Lack of irrigation & 26 & 1.66 & XIII \\
\hline
\end{tabular}

Table.3 Pull factors for migration as perceived by tribal migrants

\begin{tabular}{|c|c|c|c|c|}
\hline $\begin{array}{l}\text { Sl. } \\
\text { No. }\end{array}$ & Pull factors & Total score & Per cent & Rank \\
\hline 1 & $\begin{array}{l}\text { Superior opportunity for } \\
\text { employment and occupation }\end{array}$ & 1071 & 99.16 & I \\
\hline 2 & Better job security & 1035 & 95.83 & II \\
\hline 3 & $\begin{array}{l}\text { Superior opportunity to earn } \\
\text { higher income }\end{array}$ & 963 & 89.16 & III \\
\hline 4 & $\begin{array}{l}\text { Opportunity to obtain } \\
\text { desired } \\
\text { education, skill or training }\end{array}$ & 792 & 73.33 & IV \\
\hline 5 & $\begin{array}{l}\text { Dependency movement like } \\
\text { migration of bride to join } \\
\text { her husband }\end{array}$ & 468 & 43.33 & V \\
\hline 6 & $\begin{array}{l}\text { Preferable environment, } \\
\text { living conditions }\end{array}$ & 315 & 29.16 & VI \\
\hline 7 & $\begin{array}{l}\text { Lure to new or different } \\
\text { activities or environment }\end{array}$ & 189 & 17.50 & VII \\
\hline 8 & Better food & 72 & 6.66 & VIII \\
\hline 9 & Better social network & 9 & 0.83 & IX \\
\hline
\end{tabular}


In conclusion, regarding pattern of migration of tribal migrants and the distribution of tribal migrants based on the nature of migration, majority $(60.83 \%)$ of tribal migrants were daily migrants, 39.16 per cent of respondents were seasonal migrants and none of them migrated permanently. Regarding nature of migration based on origin and destination of movement, 98.33 per cent of respondents migrated to other states and only 1.66 per cent migrated to other districts. None of them migrated within their local area. The study also revealed that all the tribal migrants moved in groups. Most of the tribal migrants (93.33 per cent) moved to migratory places by induced decision. Regarding the purpose of migration 97.50 per cent of tribal migrants went for agriculture labour work whereas only 2.520 per cent of respondents went for non agricultural labour work. 86.66 per cent of tribal migrants were non registered migrants whereas only 13.33 per cent of tribal migrants were registered migrants. The study indicated unemployment or loss of employment as the main push factor responsible for migration. Low wages was ranked as second major push factor responsible for migration. The third major push factor responsible for migration was poverty and malnutrition. Possession of small holdings and decline of natural resources ranked fourth and fifth major push factors respectively.

Study indicated that an over whelming majority of the respondents (99.16 per cent) ranked superior opportunity for employment and occupation as first and the main pull factor responsible for migration. Better job security was the second major pull factor responsible for migration. Superior opportunity to earn higher income, opportunity to obtain desired specialization, education, skill or training and better food ranked third, fourth and fifth major pull factors of migration respectively.

\section{References}

Anh, D. N. 1999. Market Reforms and Internal labour Migration in Vietnam. Asian \& Pac migration J. 8 (3): 381407.

Babu, A., 2018. State response towards human rights violations among Adivasis in Wayanad District.

Bagchi, K.K. and S. Majumdar.2010. Dynamics of Out-Migration of Agricultural Labourers: A Micro-Level Study in Two Districts Of West Bengal. Agric. Econ. Res. Rev. 24: 568-575

Das, S. and Das, M. 2014. Income, Migration $\&$ Social Adjustment of the Tribal People in Tripura: A case study of 'Tripuri' tribe. J. Space and Culture, India, 2(1): 5-13

de Haan, A. (2000) Migrants, Livelihoods, and Rights: The Relevance of Migration in Development Policies. Social Development Working Paper 4. London: DFID.

Deshingkar, P., 2010. Migration, remote rural areas and chronic poverty in India. ODI.

Deshingkar, P., and Start, D. (2003) Seasonal Migration for Livelihoods in India: Coping, Accumulation and Exclusion. Working Paper 220. London: ODI.

Dugbazah, J. E. 2008. Gender, Migration and Rural livelihoods in Ghana: A Case of the Ho District. Unpub. PhD. Thesis, The University of Birmingham, United Kingdom, 32p

FAO. 2008. The livelihood assessment toolkit: Analysing and responding to the impact of disasters on the livelihoods of people. Food and Agriculture Organisation of the United Nations, Rome.pp.28-49

Gowda, S. and Shivashankar, G. P. 2007. Rural Migration to the Indian Metropolis: Case Study Banglore. ITPI J. 4(1): 67-69 
Kishore, K. and Kiran, V. 2013. Labour Migration - A Journey from Rural To Urban. J. Business Manag. \& Social Sci. Res. 2(5): 61-66

Llewelyn, S. (2005) 'Globalization and Labour Migration in Betul district, Madhya Pradesh: A Case Study'. IndoCanadian Shastri Applied Research Project (SHARP). New Delhi: Jawaharlal Nehru University.

Lolaksha Nagaveni, P. and Anand, A., 2017. Migration and Poverty: An Indian Reality. Social Action, 67(1), pp.32-50.

Mahapatro, S. R. 2010. Patterns and determinants of female migration in India: Insights from census. Institute for Social and Economic Change, Banglore,pp.13-16

Martin, S.F., 2004. Refugee women. Lexington books.pp 108-147

Moosan, H., Stanley, A., Vijayakumar, K., Jayasree, A.K., Lawrence, T. and Veena, A., 2019. Impediments to optimal health-care utilization of a particularly vulnerable tribal group in Wayanad: a qualitative study. Indian journal of community medicine: official publication of Indian Association of Preventive \& Social Medicine, 44(Suppl 1), p.S62.

Narain, U., S. Gupta and K. van 't. Veld (2005) Poverty and the Environment: Exploring the Relationship between Household Incomes, Private Assets, and Natural Assets. Working Paper 134. New Delhi: Centre for Development Economics, Department of Economics, Delhi School of Economics.

Oraon, V., 2012. Changing Pattern of Tribal
Livelihoods: A Case Study in Sundargarh District, Odisha (Doctoral dissertation).

Prasanth, P. 2016. A Peep in to the Tribal Problems of Wayanad with Special Reference to Kattunayakas. IJIR J. 2(6): 539-543.

Rogaly B. and D. Coppard (2003) 'They Used to Go to Eat, Now They Go to Earn: The Changing Meanings of Seasonal Migration from Puruliya District in West Bengal'. Journal of Agrarian Change 3(3): 395-433.

Rozelle, S., Taylor, J. E. and Brauw, A. De. 1999. Migration, Remittances and Agricultural productivity in China. American Econ. Rev. 89 (2): 287-291

Sadath, A., Jose, K., Meethal, S.T., Mathai, J.K., Venugopal, A.P. and Xavier, N., 2019. Factors associated with alcohol misuse among indigenous tribal men in Wayanad: A qualitative study. Indian journal of psychological medicine, 41(6), pp.516-522.

Speranza, C.I., Wiesmann, U. and Rist, S., 2014. An indicator framework for assessing livelihood resilience in the context of social-ecological dynamics. Global Environmental Change, 28, pp.109-119.

Sundari, S., 2007. Migrant women and urban labour market: Concepts and case studies of problems, gains, and losses. Deep and Deep Publications.

Vinayakam, K. and Sekar, S.P. 2013. Rural To Urban Migration in Indian Metroplis: Case Study Chennai City. $J$. Humanities \& Social Sci. 6(3): 32-35

\section{How to cite this article:}

Mano Sandesh, V. V., A. Anil Kumar and Smitha, K. P. 2021. Nature and Factors Affecting Tribal Labour Migration of Wayanad District of Kerala. Int.J.Curr.Microbiol.App.Sci. 10(02): 3489-3495. doi: https://doi.org/10.20546/ijcmas.2021.1002.384 